DOI: $10.32703 / 2415-7422-2021-11-1-68-83$

\title{
Hercules Sakkas
}

University of Ioannina

University Campus, P.O. Box: 1186, Ioannina, Greece, 45110

e-mail: isakkas@uoi.gr

https://orcid.org/0000-0002-2495-8374

\section{Panagiota Spyropoulou}

University of Ioannina

University Campus, P.O. Box: 1186, Ioannina, Greece, 45110

e-mail: pmd0083@uoi.gr

https://orcid.org/0000-0002-2474-7307

\section{The legacy of Saint Luke (Valentin Felixovich Voyno-Yasenetsky) to medical sciences}

Abstract. Saint Luke, Archbishop of Simferopol and Crimea (1877-1961), was born Valentin Felixovich Voyno-Yasenetsky in Kerch, Crimea. He served as an outstanding physician and Academic Professor of Topographic Anatomy and Operative Surgery at Medical School of Tashkent University. He worked extensively on the fields of surgery, regional anesthesia, pyogenic infections, ophthalmology, neurosurgery, oncology, orthopedics, otorhinolaryngology, gynecology, urology, and dentistry, often under difficult circumstances. He performed a wide variety of operations, from minor outpatient procedures to extremely complicated ones, followed by extensive inpatient management and treatment of ailing individuals. He published numerous research articles and books. His most acclaimed monograph entitled "Essays on the surgery of pyogenic infections" ("Sketches of purulent surgery"), focused on the broad field of surgery with special reference to the pyogenic infections and served as a reference tool and guide book for the next generations of physicians. The Stalin Prize was the highest professional honor awarded to Valentin Felixovich Voyno-Yasenetsky by the Soviet state in recognition of his contribution to science. Voyno-Yasenetsky was a blessed physician who had a major influence on both patients and colleagues, due to his fundamental ethical principles and values based on Christian beliefs. His life and scientific work have been an example of the practical unity of scientific truth and religious faith. He was ordained to the diaconate and priesthood, until he elevated to the ranks of Bishop and Archbishop. He was arrested and subsequently exiled for his religious beliefs and his glorification by the Orthodox Church as Saint Luke was held in Russia in 2000, as a recognition of God's holiness manifesting in his life. Saint Luke received an honorable place in the history of 
Medicine and the Eastern Orthodox Church. The present study aims to highlight key elements of his life and his scientific contributions.

Keywords: Saint Luke; Voyno-Yasenetsky; medicine; science; Simferopol

\section{Introduction.}

Saint Luke, Archbishop of Simferopol and Crimea (1877-1961), was born Valentin Felixovich Voyno-Yasenetsky (Валентин Феликсович Войно-Ясенецкий (in Russian)) in Kerch (Antonopoulos, 2017, p. 23), one of the most ancient cities of Crimea, originated in the 6th century BC as the Greek colony of Panticapaeum (Kubijovyč, 1988) (Fig. 1). Valentin was the third of five children (Pavel, Olga, Valentin, Vladimir and Victoriya) of a pious Catholic pharmacist father (Felix Stanislavovitch Voino Yassenesco, Феликс Станиславович Войно-Ясенецко (in Russian)) and an Orthodox mother (Mariya Dmitriyevna, Мария Дмитриевна (in Russian)). Although the Voyno-Yasenetskys were a powerful family and several generations worked traditionally at the Polish and Lithuanian courts, his family had adopted a simple and humble way of living (Popovsky, 1979; Baloyannis, 2015; Begiev, Begiev, \& Yakovleva, 2020).

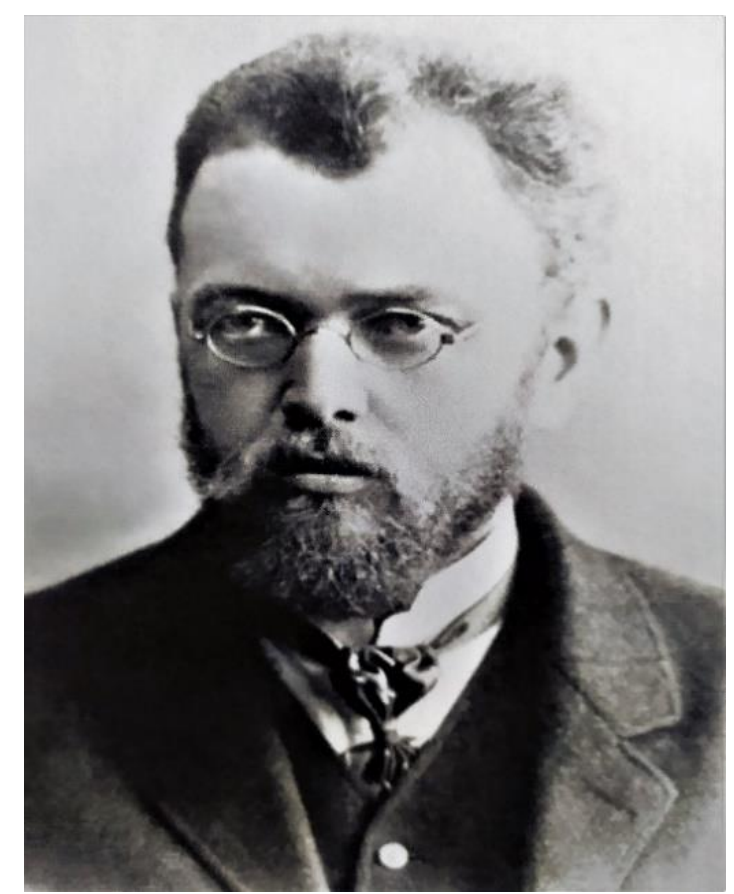

Figure 1. Valentin Felixovich Voyno-Yasenetsky (1877-1961) (Antonopoulos, 2017, p. 68).

He began his elementary education at Kiev's high school and University of Law, then moved to Munich to continue his studies at the School of Fine Arts, and finally he graduated with honors from the Great Prince St. Vladimir Medical School of the University of Kiev (Baloyannis, 2015; Andreev \& Ostroushko, 2017). After receiving his secondary education, Voyno-Yasenetsky enhanced his knowledge and expertise in 
the art of painting, although he never completed art studies (Antonopoulos, 2017, p. 30). Thus, during his introductory session and evaluation examination at the Saint Petersburg Academy of Arts, he understood that his true calling was to relieve pain from suffering people by studying the art of medicine (Kaladze, 2016).

After his graduation from the Medical School of the University of Kiev, he served as an outstanding physician and Academic Professor of Topographic Anatomy and Surgery (Baloyannis, 2015; Andreev \& Ostroushko, 2017). As a surgeon he was the founder of purulent surgery performing several procedures and describing key anatomical landmarks as well (Morgoshiya \& Apchel, 2018). His research interests involved surgery and anatomy with emphasis on the development of surgical and anesthesia methods, organ transplantation, treatment of pyogenic infections, wounds, osteomyelitis, and several systemic abnormalities (Baloyannis, 2015; Ditkovskaia, 2017). His scientific work includes 55 research articles and books, covering the period from 1908 to 1956, while he was awarded the State Stalin Prize in Medicine in 1946 (Baloyannis, 2015; Andreev \& Ostroushko, 2017).

Voyno-Yasenetsky was married to Anna Vasilievna Lanskaya (Анна Васильевна Ланская) and had four children (Michael, Helen, Alexios and Valentine). Anna Lanskaya was a gentle and moral nurse who served in the Kiev Military Hospital and in Russo-Japanese war and died from pulmonary tuberculosis (Antonopoulos, 2017, pp. 83-85). According to the doctrines of the Orthodox Church, their children were treated with love, decency, and respect, whereas all of them studied in Health Sciences including Medicine, Epidemiology and Biology (Baloyannis, 2015).

Voyno-Yasenetsky was an eminent and powerful person who had a major influence on both patients and colleagues, due to his fundamental ethical principles and values based on Christian beliefs and philosophy (Ditkovskaia, 2017). He was ordained to the diaconate and priesthood, until he elevated to the ranks of Bishop and Archbishop. He was arrested and subsequently exiled for his religious beliefs twice to the Krasnoyarsk region of Eastern Siberia and once to the shores of the White Sea (Popovsky, 1979). His glorification by the Orthodox Church as Saint Luke was held in Russia in 2000, as a recognition of God's holiness manifesting in his life (Andreev \& Ostroushko, 2017).

Following the adoption of new scientific innovations, medical ethics and high moral principles deriving from his religion, Valentin Felixovich Voyno-Yasenetsky received an honorable place in the history of Medicine and the Eastern Orthodox Church (Mylantyeva, Nebylitsin, \& Pipipayt, 2010). His life and scientific work have been an example of the practical unity of scientific truth and religious faith (Kozovenko, 2015). The aim of the present study aims to highlight key elements of Voyno-Yasenetsky's life and scientific work and his contribution to Medical Sciences.

\section{Theoretical Foundations.}

An overview of Voyno-Yasenetsky's life and scientific work was based on specific historical, biographical, and scientific sources, included in relevant published 
studies. Based on this specific knowledge base, and by summarizing, aggregating, organizing, comparing and finally evaluating and highlighting the key points of the evidence extracted from the used literature, the results including three principal sections (medical career and surgical contributions, research interests, and spiritual life), the discussion and conclusions of the current study, contribute to existing knowledge.

\section{Results and discussion.}

\section{Medical career and surgical contributions.}

As a medical student Voyno-Yasenetsky received significant skills in the areas of surgery, microbiology, ophthalmology and orthopedics during his training. Thus, during his education he was able to identify some of the common etiological agents responsible for causing pyogenic infections by observing microorganisms under the light microscope, to make early and accurate diagnosis of ocular comorbidities and executing routine orthopedic and surgical procedures following aseptic guidelines (Shevchenko, 2011, pp. 19-38). After completing his graduation from Medical School in 1903 and during the World War I, Voyno-Yasenetsky obtained surgical experience as a member of the Kiev Medical Hospital of the Red Cross (Baloyannis, 2015), serving as a surgeon and chief physician of the infirmary for the injured soldiers and also started working as a provincial doctor in the hospitals of Simbirsk, Kursk, Saratov and Vladimir regions (Morgoshiia, 2019; Begiev, Begiev, \& Yakovleva, 2020). He also gained considerable experience in ophthalmology, serving at Kiev's Eye Clinic (Kaladze, 2016).

Working alone in small hospitals of rural areas, including Ardatov, Fatezh, Liubazh, and Pereslavl-Zalessky he performed a thousand procedures every year (Popovsky, 1979; Kaladze, 2016) (Fig. 2). In 1917, he was appointed surgeon-in-chief at the Tashkent General Hospital, and in 1919 he was elected Professor of Topographical Anatomy and Operative Surgery at Medical School of the newly established Tashkent University (Baloyannis, 2015; Morgoshiya \& Apchel, 2018). He worked as a surgeon in Bolshaya Murta, Krasnoyarsk Krai, from 1937 until 1941 (Andreev \& Ostroushko, 2017), and during this period he was performing about five to six major operations a day, under very difficult circumstances, without eating properly or looking after himself. However, his letters from Krasnoyarsk during this period are full of happiness, hope and faith, because nothing could be comparable with his great scientific destination (Popovsky, 1979). At the end of his career, and after serving in the Great Patriotic War, he was assigned to the Army Hospital and Hospital of Veterans, in Simferopol of Crimea, as chief surgeon and consultant (Kosachev, Gladkikh, \& Iakovlev, 2011; Baloyannis, 2015).

Voyno-Yasenetsky made magnificent contributions not only to the field of surgery and pyogenic infections, but also to anesthesiology, ophthalmology, neurosurgery, oncology, orthopedics, otorhinolaryngology, gynecology, urology and dentistry (Mylantyeva, Nebylitsin, \& Pipipayt, 2010). He performed a wide variety of 
operations, from minor outpatient procedures to extremely complicated ones, followed by extensive inpatient management and treatment of ailing individuals (Baloyannis, 2015). Up to that time, patients usually died not because of unsuccessful surgical interventions, but from the fact that they could not endure anesthesia. VoynoYasenetsky introduced a new method of regional anesthesia, which in terms of side effects was a more benign technique when compared to conventional local and general ether and chloroform anesthesia procedures (Begiev, Begiev, \& Yakovleva, 2020). After extensive research, he was the first physician who provided local anesthesia in order to treat the trigeminal neuralgia, by injecting local anesthetic solution into the area where the second branch of the nerve leaves the skull through the foramen rotundum (Baloyannis, 2015).

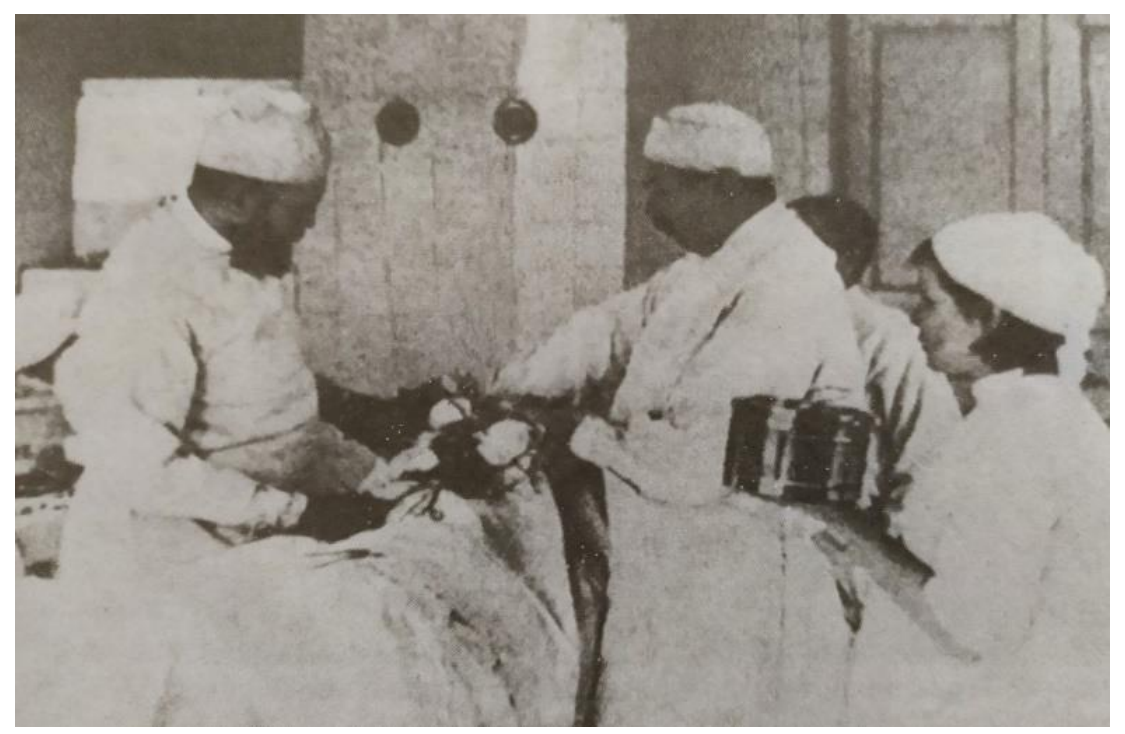

Figure 2. Valentin Felixovich Voyno-Yasenetsky (left) performing an operation in Pereslavl-Zalessky hospital (Antonopoulos, 2017, p. 65).

Having experience in microbiology, he worked extensively on the field of bacterial and fungal pyogenic infections, treating pyogenic infections and septic wounds by using surgical procedures as the sole therapeutic method (VoinoYasenetsky, 2011) much earlier than the antibiotic era started with the first initial observation and discovery of penicillin by Fleming in 1929 (Aminov, 2010).

He pioneered many techniques within the spectrum of surgery, including laparotomies, neurosurgical and ophthalmological (e.g. iridectomy and lacrimal sac removal using simplified local anesthesia) procedures, resection of the upper jaw, gynecological and pediatric surgical operations (Baloyannis, 2015). Besides, he gained a great reputation as a surgeon and he also received professional honor for his contribution, after his name was linked to several innovative procedures and topographic anatomical landmarks primarily undergone by him. Examples include the pelvic resection by Voyno-Yasenetsky, the Voyno-Yasenetsky operation of excision of the affected skin and fatty tissue of the axillary fossa due to multiple hidradenitis, 
the original Voyno-Yasenetsky closure method of the traumatic diaphragm injury, the Voyno-Yasenetsky incision of the popliteal fossa, and the Voyno-Yasenetsky's line and point anatomical landmarks, referring to the projection and exit of the sciatic nerve at the gluteal region, respectively (Morgoshiya \& Apchel, 2018; Morgoshiia, 2019).

Vonyo-Vaseyetsky's contribution to transplants was also significant. By the end of 1910s, the first kidney xenotransplant experiments in humans were performed by Jaboulay and Unger, using kidneys from domestic animals (pigs, goats) and monkey donors respectively, but all the patients died soon, since these early human kidney xenografts functioned just for a short-term period (Barker \& Markham, 2013). Later, as the concept of kidney transplantation was extensively established by French and American surgeons, it was stated that renal transplantation should be more effective using organs from nonhuman species, since the availability of kidneys from humans was extremely limited and chronic hemodialysis had not been developed yet (Cooper, 2012). In 1924, at the Yeniseysk town hospital, Krasnoyarsk Krai, Voyno-Yasenetsky performed successfully the world's first kidney xenotransplantation from calf to a peasant suffering from uremia (Popovsky, 1979), while a decade later, Yurii Voronoy from Ukraine achieved the first human allograft renal transplantation (Matevossian et al., 2009).

Twelve years after performing his first splenectomy in 1911, on a patient due to a traumatic rupture who died five days later from necrosis of the large intestine, VoynoYasenetsky proposed a new method of spleen removal and ligation of blood vessels, as an addition to the existing data of described anatomical structure and the operation established by other scientists (Kozovenko, 2015; Morgoshiya \& Apchel, 2018). With this new scientific procedure, referred as the "Voyno-Yasenetsky method", the outstanding surgeon aimed to lower the incidence rates of surgery-related deaths and complications (Kozovenko, 2015). An additional innovative modification to a generally accepted Halsted's procedure by Voyno-Yasenetsky concerned surgery after breast cancer accompanied by lymph node removal, by which he could identify underlying comorbidities including metastases and tuberculous lymphadenitis (Kozovenko, 2015). Halsted was one of the most distinguished surgeons in American medicine, who served as a professor of surgery at the Johns Hopkins hospital in Baltimore, in the late 19th century (Rutkow, 1987). After the war, Voyno-Yasenetsky contributed to rural population health by covering a wide range of procedures, including the widespread blinding trachoma (Popivanov, 2018). In such a case he operated on a whole family where the father, mother, and five of their children were blind since birth (Begiev, Begiev, \& Yakovleva, 2020).

\section{Research interests.}

Author of 55 scientific papers and books on the fields of surgery and anatomy, Professor Voyno-Yasenetsky worked unceasingly suffering from certain underlying medical conditions, including diabetes, heart disease, gout, relapsing fever, and deteriorating vision (Popivanov, 2018). Numerous case reports and surgical 
interventions were provided concisely and simply in his works, as a source of creative inspiration, accumulation of knowledge and experience (Kaladze, 2016). His research interests focused on general surgery, regional anesthesia and surgical treatment of pyogenic infections. In 1915, he published his first important scholarly work with his own illustrations in Saint Petersburg, entitled "Regional anesthesia", as part of his dissertation thesis which he successfully defended one year later in Moscow. In his dissertation, the results of his extensive surgical procedures, an overview of peripheral nerve anatomy, along with the development of new skills for the regional anesthesia in the lower limbs and performance of efficient peripheral blocks of trigeminal, sciatic and median nerves were described thoroughly. For this work, he was awarded the Chojnacki prize by the Warsaw University, granted to the best original scientific research "Blazing new trails in the field of medicine". At that time, his first clinical cases reports entitled "Elephantiasis of the face, due to plexiform neurinoma" and "Retrograde strangulated inguinal hernia" were also published (Baloyannis, 2015; Popivanov, 2018).

During one of his exile periods to the Krasnoyarsk Krai, two of his original works were published in the scientific journal "Deutsche Zeitschrift für Chirurgie" under the name Lucas Bischof, entitled "On the suturing of vessels during the removal of the spleen", and "The necessity of increasing the operation area for operations related to malignant breast tumors". Publishers used "Lucas" as the first name and "Bischof" as the surname for Bishop Luke. Due to his arrest and exile to Krasnoyarsk and Turukhansk, Voyno-Yasenetsky could not correct the inaccuracy of the German translation. This led to the belief in scientific societies of Western Europe that the surgeon Lucas Bischof, was other than Voyno-Yasenetsky. For most of the next eight decades, these achievements remained relatively unknown within Eastern scientific community (Kozovenko, 2015).

In 1934, he published his most acclaimed monograph entitled "Essays on the surgery of pyogenic infections" ("Sketches of purulent surgery"), after at least ten years of preparation. In its first three editions (1934, 1945, 1956), the monograph was released in 60,000 copies. In November 2011, the 1st volume was published for the first time in Greek by "Akritas Publications", while in October 2014 the publication was completed with the release of the 2 nd volume by "Porphyra Publications", both edited by surgeon Grigorios Lakiotis and Metropolitan of Argolis Nektarios Antonopoulos (Mylonas, Poulakou-Rebelakou, \& Papadopoulou, 2017). Based on a thorough and comprehensive analysis of his personal experience on surgical treatment and dissection of thousand patients and corpses in the morgue, as well as on precise knowledge of topographic anatomy and comprehensive review of the international literature, this work focused on the broad field of surgery with special reference to the pyogenic infections and served as a reference tool and guide book for the next generations of physicians (Voino-Yasenetsky, 2011; Kozovenko \& Bogopolsky, 2016; Mylonas, Poulakou-Rebelakou, \& Papadopoulou, 2017; Popivanov, 2018) (Table 1). 
Table 1. Surgical, and clinical issues included in "Essays on the surgery of pyogenic infections".

\begin{tabular}{|c|c|}
\hline Surgical pathology & Infectious diseases \\
\hline Scalp wounds & Meningitis; Encephalitis \\
\hline $\begin{array}{c}\text { Phlegmon and osteomyelitis of the } \\
\text { craniofacial skeleton }\end{array}$ & $\begin{array}{c}\text { Ludwig's angina; Laryngitis; } \\
\text { Diptheria }\end{array}$ \\
\hline Skin infections; Cellulitis; Erysipelas & Pneumonia; Bronchitis \\
\hline Furuncles; Carbuncles & Tuberculosis \\
\hline Ocular pyogenic granulomas & Actinomycosis \\
\hline Acute parotitis; Acute otitis media & Septic arthritis; Septic pericarditis \\
\hline Periostitis; Osteomyelitis & Typhoid and paratyphoid fever \\
\hline Inflammatory joint and bone diseases & Syphilis \\
\hline Pleurisy; Lung abscess; Mastitis & Hepatitis \\
\hline Infection of iliac fossa and psoitis & Influenza \\
\hline Appendicitis; Peritonitis & Measles \\
\hline Liver abscess; Spleen abscess & Scarlet fever; Smallpox \\
\hline Lymphangitis; Sarcoma & Relapsing fever \\
\hline $\begin{array}{c}\text { Retroperitoneal abscess; Perianal } \\
\text { abscess }\end{array}$ & Malaria; Amoebiasis; \\
Leishmaniasis
\end{tabular}

Microbiological issues were also included in "Essays on the surgery of pyogenic infections" (current approved bacterial names are given in parentheses): Staphylococcus aureus; Staphylococcus albus (epidermidis); $\beta$-hemolytic Streptococci; viridans Streptococci; Pneumoniococcus (Streptococcus pneumoniae); Neisseria meningitidis; Gonococcus (Neisseria gonorrhoeae); Escherichia coli; Friedlander's bacillus (Klebsiella pneumoniae); Proteus vulgaris; Bacillus pyocyaneus (Pseudomonas aeruginosa); Bacillus paratyphosus C (Salmonella enterica serotype Paratyphi C); Bacillus anthracis; Bacillus ramosus; Bacteroides fundiliformis; Mycobacterium tuberculosis; Bacillus welchii (Clostridium perfringens); Vibrio spp.; Spirochaetae; Entamoeba histolytica; Echinococcus spp.; Plasmodium spp.; Schistosoma spp.

The first data for the book was taken from the time of the Russo-Japanese war, while Voyno-Yasenetsky was serving as a head physician and surgeon at the Military Hospital of Chita, in 1904 (Glyanzev, 2016; Antonopoulos, 2017, pp. 41-42). Regarding the atmosphere that prevailed in Europe at the beginning of 1930s, surgeons considered that this book could serve as an extremely necessary tool in anticipation of a possible war. For both "Essays on the surgery of pyogenic infections" and a monograph entitled "Late resections for infected gunshot wounds of joints", referring to his surgical achievements in the hospitals of the Krasnoyarsk territory in 1941-1944, with an emphasis on patients with severe complications of purulent joint wound 
infections, he was awarded the prestigious State Stalin Prize of first degree in 1946 (Kozhevnikov, 2018; Morgoshiya \& Apchel, 2018).

\section{Spiritual life.}

"If you try to describe my life, do not distinguish between the surgeon and the bishop. The impression that will stand out from such a separation will be inaccurate", Voyno-Yasenetsky had told to his first biographer Mark Popovsky (Shevchenko, 2011, p. 7). When performing an operation, he used to pray for a few minutes before the beginning of each one, making the sign of the Cross on each patient's body with iodineimpregnated gauzes (Mylonas, Poulakou-Rebelakou \& Papadopoulou, 2017). During his adolescence he was influenced by two important spiritual incentives. The former one was the Kiev Pechersk Lavra (Kiev Monastery of the Caves), a historic Orthodox Christian monastery, where he used to paint his sketches as an art student (Antonopoulos, 2017, pp. 28-31). The latter was a copy of the Holy Bible which he had received as the most valuable gift upon graduating from high school (Baloyannis, 2015). But also living in love and faith with his family, allowed Voyno-Yasenetsky to find fulfillment in his life according to the Christian beliefs and values.

In 1921, he was ordained a deacon continuing his work at hospital, while one week later he was ordained to the priesthood by Diocesan Bishop Innokenty of Tashkent, in a difficult time for the Orthodox Church. During this period, an antireligious campaign had begun in the Soviet Union, but Fr. Valentin continued undisturbed to preach at Tashkent Cathedral (Baloyannis, 2015). In 1923 he was tonsured a monk and consecrated a Bishop Luke in honor of the Holy Apostle and Evangelist Saint Luke the Physician. During the period 1923-1943, he was captured, sent to prison, and exiled numerous times due to his Christian faith, living under harsh isolation and painful weather conditions (Kozovenko \& Bogopolsky, 2016; Begiev, Begiev, \& Yakovleva, 2020). For over a decade he lived painfully in Omsk, Novosibirsk, Krasnoyarsk, Yeniseysk, Turukhansk, Arkhangelsk and Bolshaya Murta, all located thousands of kilometres away from his home, and although his health was gradually worsening, he continued healing hundreds of patients, teaching the young doctors, performing surgical operations, preaching and writing both research reports and sermons (Popovsky, 1979; Baloyannis, 2015). People used to show appreciation and express their gratitude to him in several ways, asking for his blessing. Interestingly, when he moved from Turukhansk to the northernmost regions of the Arctic Ocean region, residents managed to collect warm clothes and furs for him, saving his life (Popovsky, 1979).

During the invasion of the Soviet Union by Germans, Bishop Luke asked the central government to be moved to the front and serve as a surgeon. For his medical services as a chief surgeon of the army hospital in Krasnoyarsk at the outbreak of World War II, he was awarded the medal "For valiant labour in the Great Patriotic War 19411945" (Antonopoulos, 2017, p. 367). In 1942, he was elevated to the rank of Archbishop and in 1945, he was merited the right to wear the Diamond Cross by 
Patriarch Alexy I (Andreev \& Ostroushko, 2017). In 1946 he assumed the position of the Archbishop of Simferopol and Crimea (Fig. 3), while he was also elected to honorary membership of the Moscow Theological Academy since his publicized sermons were recognized as unique in ecclesiastic theology (Antonopoulos, 2017, p. 470).

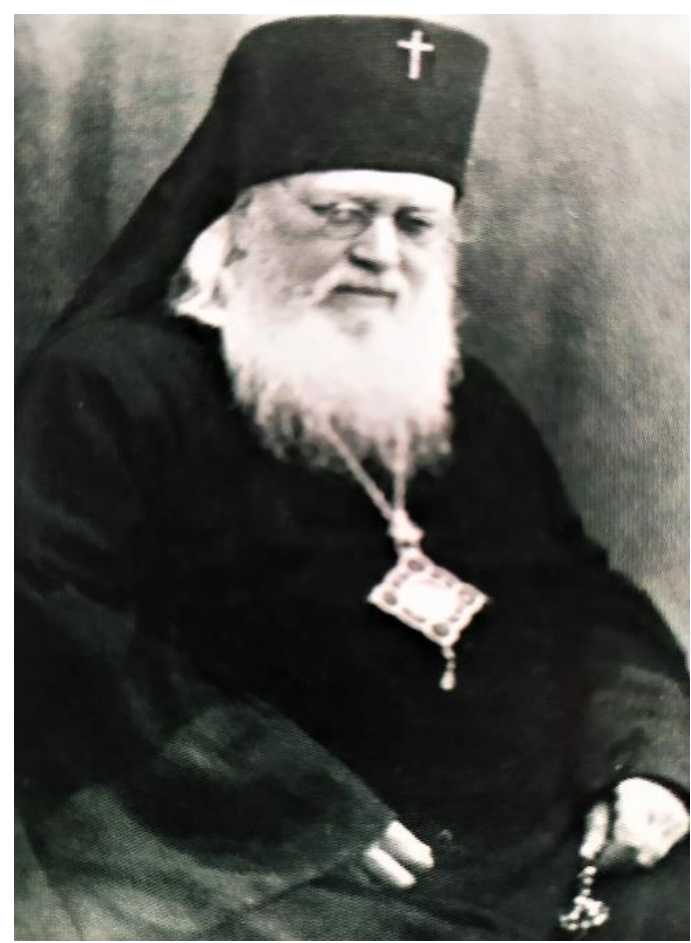

Figure 3. Saint Luke, Archbishop of Simferopol and Crimea (Antonopoulos, 2017, p. 419).

Among his written heritage as theologian, consisting of 1250 sermons published in 12 volumes the memorable book entitled "The Spirit, the Soul and the Body", was characterized as a significant achievement in science, theology and philosophy (Baloyannis, 2015; Popivanov, 2018). Based on his extensive scientific and philosophical background, as well as his Orthodox Christian beliefs and values (Baloyannis, 2015), Archbishop Luke used all the available literature in physics, chemistry, psychology, psychiatry and theology in order to prove that man consists of a nonmaterial spirit and soul as well as a body (Popovsky, 1979). To this end, he believed that the spirit is the true essence of human, and that both the soul and body act as mediator between him and the world, interacting at the point of the act of human consciousness (Zaluzhna \& Veremeichyk, 2020).

In 1955, he was completely blind and retired from his medical duties, but he continued to preach and lead the diocese. In 1959, he had to deal once again with an unprofessional behaviour of his academic colleagues due to his Christian beliefs. He declared: "Our great physiologist Pavlov, the academician Vladimir Petrovich Filatov, the priest-scientist and astronomer Nicolaus Copernicus, and Louis Pasteur, were able to combine scientific work with their deep faith to God" (Antonopoulos, 2017, 
pp. 460-461). He died peacefully in 1961, and he was buried with honor in the All Saints cemetery of Simferopol. In 1995, Archbishop Luke was canonized as locally venerated saint of the Crimean diocese, while in 2000, he was glorified as Saint in the Assembly of new martyrs and Confessors of Russia by the Russian Orthodox Church (Andreev \& Ostroushko, 2017; Antonopoulos, 2017, pp. 503-504; Popivanov, 2018; Begiev, Begiev, \& Yakovleva, 2020).

\section{Conclusions.}

Voyno-Yasenetsky was a pioneer surgeon and academic professor. He worked extensively on the field of general surgery, pyogenic infections and regional anesthesia and published numerous research articles and books. He pioneered many innovative procedures within the spectrum of several surgical specialties. He treated the wounded patients and taught the young doctors. Among his research works, the monograph entitled "Essays on the surgery of pyogenic infections" served as a reference tool and guidebook for the next generations of physicians. He received professional honor for his contribution, after he was awarded the State Stalin Prize of first degree. As a theologian, philosopher, and bishop, he dedicated his life not only to the medical science and suffering people but to the Orthodox Church as well. After living a simple, genuine, and pure life, he elevated to the rank of Archbishop and he was glorified as Saint Luke by the Russian Orthodox Church. Following the adoption of new scientific innovations in the field of Medicine Saint Luke (Valentin Felixovich VoynoYasenetsky) received an honorable place in the history of Medical Sciences.

\section{Acknowledgments.}

We wish to acknowledge Metropolitan Nectarios (Antonopoulos) of Argolis for providing all valuable information, references, and books about the life of Saint Luke. We are forever grateful for his wisdom. We are also grateful to Fr.I who was a mentor to us and always present in our hearts. We thank Mrs Sionti, G.V, N.R, P.B, F.Ms and our colleagues for their continual support.

\section{Funding.}

This research received no external funding.

\section{Conflicts of Interest.}

The authors declare no conflict of interest.

\section{References}

Aminov, R. I. (2010). A brief history of the antibiotic era: lessons learned and challenges for the future. Frontiers in Microbiology, 1, 134. https://doi.org/10.3389/fmicb.2010.00134. 
Andreev, A. A, \& Ostroushko, A. P. (2017). Vojno-Yaseneckij Valentin Feliksovich(1877-1961). K 140-letiyu so dnya rozhdeniya [Voyno-Yasenetsky Feliksovich (1877-1961). To the $140^{\text {th }}$ of the birthday]. Vestnik Eksperimental'noj i Klinicheskoj Hirurgii - Journal of Experimental and Clinical Surgery, 10, 174. https://doi.org/10.18499/2070-478X-2017-10-2-174 [in Russian].

Antonopoulos, N. (2017). Archbishop Luke, A holy Shepherd and surgeon (18771961). Athens, Greece: Porfyra Publications [in Greek].

Baloyannis, S. (2015). Saint Luke Metropolitan of Simferopol as physician, surgeon and academic professor. Encephalos, 52, 37-52.

Barker, C. F, \& Markmann, J. F. (2013). Historical overview of transplantation. Cold Spring Harbor Perspectives in Medicine, 3, a014977. https://doi.org/10.1101/cshperspect.a014977.

Begiev, V. G, Begiev, O. V, \& Yakovleva, N. R. (2020). Valentin Feliksovich VojnoYaseneckij (Svyatitel' Luka) [Valentin Feliksovich Voino-Yasenetsky (Saint Luke)]. Paradigmata Poznání, 2, 37-41. Retrieved from http://sociosphera.com/files/conference/2020/pp_2-20.pdf [in Russian].

Cooper, D. (2012). A brief history of cross-species organ transplantation. Proceedings (Baylor University. Medical Center), 25, 49-57 https://doi.org/10.1080/08998280.2012.11928783.

Ditkovskaia, I. (2017). Eticheskie principy V. F. Vojno-Yaseneckogo aspekte filosofii lichnostnogo obrazovaniya [Ethical principles of V. F. Voyno-Yasenetsky in the context of personal education philosophy]. Bioetika - Bioethics, 2, 43-45. Retrieved from https://journals.eco-vector.com/2070-1586/article/view/55016 [in Russian].

Glyanzev, S. P. (2016). "Ocherki gnojnoj hirurgii” Svyatitelya Luki (VojnoYaseneckogo): sud'ba knigi-legendy v zerkale stoletij (k 140-letiyu so dnya rozhdeniya V. F. Vojno-Yaseneckogo) ["Sketches of purulent surgery" of St. Luka (Vojno-Jaseneckij): a legend book's destiny in the mirror of centuries (by the 140th anniversary of Vojno-Jaseneckij's birth)]. Rany $i$ Ranevye Infekcii. Zhurnal im. Prof. B. M. Kostyuchyonka - Wounds and Wound Infections. The Prof. B. M. Kostyuchenok Journal, 3(4), 10-23 https://doi.org/10.17650/24089613-2016-3-4-10-23 [in Russian].

Kaladze, N. N. (2016). Tvorcheskij put' V. F. Vojno-Yaseneckogo v medicine [The career V. F. Voino-Yasenetsky in medicine]. Rany i Ranevye Infekcii. Zhurnal im. Prof. B. M. Kostyuchyonka - Wounds and Wound Infections. The Prof. B. M. Kostyuchenok Journal, 3(3), 8-14 https://doi.org/10.17650/24089613-2016-3-3-8-14 [in Russian].

Kosachev, I. D, Gladkikh, P. F, \& Iakovlev, A. E. (2011). Nauchnaya, pedagogicheskaya i hirurgicheskaya deyatel'nost' professora V. F. VojnoYaseneckogo v period Velikoj Otechestvennoj vojny [Scientific, pedagogical, and surgical work of professor V. F. Voyno-Yasenetsky during the Great Patriotic War]. Voenno-Medicinskij Zhurnal - Voenno-Meditsinskii Zhurnal, 332(8), 82- 
89. Retrieved from https://sc.mil.ru/files/morf/military/archive/8_2011.pdf [in Russian].

Kozhevnikov, S. V. (2018). O soderzhanii raboty V. F. Vojno-Yaseneckogo s ranenymi i bol'nymi v Krasnoyarskom krae v 1941-1944 gg. [On the content of V. F. Voyno-Yasenetsky's work with the wounded and the sick in the Krasnoyarsk region in 1941-1944]. Vestnik Kemerovskogo Gosudarstvennogo Universiteta - Bulletin of Kemerovo State University, (4), 39-46. https://doi.org/10.21603/2078-8975-2018-4-39-46 [in Russian].

Kozovenko, M. N, \& Bogopolsky, P. M. (2016). "Ocherki gnojnoj hirurgii” (k 70letiyu 2-go izdaniya monografii i prisvoeniya V. F. Vojno-Yaseneckomu Stalinskoj premii I stepeni) ["Sketches of purulent surgery" (on the $70^{\text {th }}$ anniversary of the $2^{\text {nd }}$ edition of the monograph and assigning V. F. VoynoYasenetsky the Stalin Prize of the first degree)]. Klinicheskaya $i$ Eksperimental'naya Hirurgiya. Zhurnal Imeni Akademika B. V. Petrovskogo Clinical and Experimental Surgery. Petrovsky Journal, 4(2), 6-17. http://doi.org/10.18821/0023-2149-2017-95-4-378-382 [in Russian].

Kozovenko, M. N. (2015). Vozvrashchenie v nauchnyj oborot vrachebnyh trudov hirurga i episkopa V. F. Vojno-Yaseneckogo [Returning the medical writings of surgeon and bishop V. F. Voyno-Yasenetsky to scientific use]. Istoriya Mediciny - History of Medicine, 2(1), 113-120. https://doi.org/10.17720/24095834.v2.1.2015.10k [in Russian].

Kubijovyč, V. (1988). Kerch. Retrieved from http://www.encyclopediaofukraine.com/display.asp?linkpath=pages $\% 5 \mathrm{CK} \% 5 \mathrm{C}$ E\% 5CKerch.htm.

Matevossian, E, Kern, H, Hüser, N, Doll, D, Snopok, Y, Nährig, J. ... Thorban, S. (2009). Surgeon Yurii Voronoy (1895-1961) - a pioneer in the history of clinical transplantation: in Memoriam at the 75th Anniversary of the First Human Kidney Transplantation. Transplant International, 22, 1132-1139. https://doi.org/10.1111/j.1432-2277.2009.00986.x.

Morgoshiia, T. S. (2019). Pamyati professora V. F. Vojno-Yaseneckogo arhiepiskopa i hirurga: k 140-letiyu so dnya rozhdeniya [In memory of professor V. F. Voyno-Yasenetsky - Archbishop and surgeon: To the $140^{\text {th }}$ anniversary from the birthday]. Tihookeanskij Medicinskij Zhurnal-Pacific Medical Journal, (1), 94-97 https://doi.org/10.17238/PmJ1609-1175.2019.1.94-97 [in Russian].

Morgoshiya, T. S, \& Apchel, V. Y. (2018). K 140-letiyu so dnya rozhdeniya VojnoYAseneckogo (arhiepiskopa Luki) [To the $140^{\text {th }}$ anniversary of the legendary Professor of surgery V. F. Voyno-Yasenetsky (Archbishop Luka)]. Vestnik Rossijskoj Voenno-Medicinskoj Akademii - Bulletin of the Russian Military Medical Academy, 20(1), 257-260. https://doi.org/10.17816/brmma12364 [in Russian].

Mylantyeva, Y. A, Nebylitsin, Y. S, \& Pilipayt, M. T. (2010). Sluzha Bogu i hirurgii [In the name of God and surgery]. Novosti hirurgii - Novosti Khirurrgii, 18(5), 
3-11. Retrieved from http://www.surgery.by/pdf/full_text/2010_5_1_ft.pdf [in Russian].

Mylonas, A, Poulakou-Rebelakou, E, \& Papadopoulou, E. (2017). Saint Luke the Physician: his contribution to the surgical management of oral, facial and neck infections. Hellenic Archives of Oral and Maxillofacial Surgery, 18(3), 129-162. Retrieved from https://www.haomsjournal.org/haoms-2017-3-129-162.html.

Popivanov, G. (2018). Tribute to prof. Valentin Voino-Iasenezkii (Archbishop Luca)

(1877-1961). International Journal of Surgery and Medicine, 4, 1-2 https://doi.org/10.5455/ijsm.prof-Valentin-Voino-Iasenezkii-Archbishop-Luca.

Popovsky, M. (1979). Archbishop Luka, surgeon and scholar. Religion in Communist Lands, 7(2), 97-105. https://doi.org/10.1080/09637497908430904.

Rutkow, I. M. (1987). The letters of William Stewart Halsted and John Chalmers

DaCosta. The American Journal of Surgery, 154(3), 320-332. https://doi.org/10.1016/0002-9610(89)90622-3.

Shevchenko, G. (2011). Greetings from Holy Hierarch St. Luke, Beloved Physician. The journey of the bishop and physician Saint Luke in the field of Medical Science. Athens, Greece: Kyriakidis-Akritas Publications S.A [in Greek].

Voino-Yasenetsky, V. F. (2011). Essays on the Surgery of Pyogenic Infections. Athens, Greece: Kyriakidis-Akritas Publications S.A. [in Greek].

Zaluzhna, A, \& Veremeichyk, S. (2020). Osoblyvist vzaiemozviazku dukhu, dushi ta tila $\mathrm{v}$ relihiino-antropolohichnykh poshukakh V. F. Voino-Yasenetskoho [The interactions between spirit, soul and body in religious and anthropological searches of V. F. Voino-Yasenetsky]. Osvitnii Dyskurs: Zbirnyk Naukovykh Prats - Educational Discourse: Collection of Scientific Papers, 21, 41-52. https://doi.org/10.33930/ed.2019.5007.21(3)-4 [in Ukranian].

\section{Херцулес Саккас}

Університет Яніни, Греція

\section{Панагіота Спіропоулоу}

Університет Яніни, Греція

\section{Спадщина Святого Луки (Валентина Феліксовича Войно-Ясенецького) в медичній науці}

Анотація. Святий Лука, архієпископ Сімферопольський і Кримський (18771961), Валентин Феліксович Войно-Ясенецький, народився у Керчі у Криму. Він був видатним лікарем, і прачював академічним професором топографічної анатомії та оперативної хірургї в медичній школі Ташкентського університету. Він багато праџював у галузі хірургії, регіонарної анестезії, гнійних інфекцій, офтальмології, нейрохірургії, онкології, ортопедії, оториноларингології, гінекології, урології та стоматології, часто за складних 
обставин. Він робив найрізноманітнімі операції, від незначних амбулаторних прочедур до надзвичайно складних, з подальшим довготривалим стаціонарним лікуванням. Він опублікував численні наукові статті та книги. Його найвідоміша монографія під назвою “Нариси хірургї гнійних інфекцій” ("Нариси гнійної хірургії”) зосереджена на широкому полі хірургії з особливостями хірургії гнійних інфекиій та послужила довідковим інструментом та путівником для наступних поколінь лікарів. Сталінська премія була найвищуюю професійною відзнакою, яку Валентин Феліксович Войно-Ясенецький отримав від радянської держави як визнання його внеску в науку. Войно-Ясенецький був талановитим лікарем, який мав великий вплив як на пацієнтів, так і на колег, завдяки свойм фундаментальним етичним принципам та иінностям, заснованим на християнських віруваннях. Його життя та наукова діяльність були прикладом практичної єдності наукової істини та релігійної віри. Він був призначений дяком і священником, а пізніше висвячений до чинів єпископа та архієпископа. Він був заарештований $i$ згодом засланий за свої релігійні вірування та прославлення православної цүеркви. В Росї̈ в 2000 році відбулося загальноцерковне прославляння святого Луки, як визнання святості Бога, шуо виявилося в його житті. Святий Лука отримав почесне місце в історії медицини та Східної Православної Церкви. Це дослідження має на меті висвітлити ключові елементи його життя та його науковий внесок.

Ключові слова: Святий Лука; Войно-Ясенецький; ліки; наука; Сімферополь

\section{Херцулес Саккас}

Университет Янины, Греция

\section{Панагиота Спиропоулоу}

Университет Янины, Греция

\section{Наследие Святого Луки (Валентина Феликсовича Войно-Ясенецкого) в медицинской науке}

Аннотация. Святой Лука, архиепископ Симферопольский и Крымский (1877-1961), родился Валентин Феликсович Войно-Ясенецкий в Керчи, Крыл. Он был выдаюшимся врачом и работал академическим профессором топографической анатомии и оперативной хирургии в медицинской школе Ташкентского университета. Он много работал в области хирургии, регионарной анестезии, гнойных инфекций, офтальмологии, нейрохирургии, онкологии, ортопедии, оториноларингологии, гинекологии, урологии $u$ стоматологии, часто в сложных обстоятельствах. Он делал самыле разные операции, от незначительных амбулаторных прочедур до чрезвычайно сложных, с последуюшим длительным стационарным лечением. Он опубликовал многочисленные научные статьи и книги. Его самая известная монография под 
названием “Очерки хирургии гнойных инфекций” (“Очерки гнойной хирургии”) сосредоточена на широком поле хирургии с особенностями хирургии гнойных инфекичй и послужила справочным инструментом и путеводителем для последующих поколений врачей. Сталинская премия была самой высокой профессиональной наградой, которую Валентин Феликсович Войно-Ясенецкий получил от советского государства как признание его вклада в науку. ВойноЯсенецкий был талантливым врачом, который имел большое влияние как на пацииентов, так и на коллег, благодаря своим фундаментальным этическим принципам и цүенностям, основанным на христианских верованиях. Его жизнь и научная деятельность были примером практического единства научной истинь и религиозной веры. Он был назначен дьяком и священником, а позже рукоположен $\kappa$ чинам епископа $и$ архиепископа. Он был арестован $u$ впоследствии сослан за свои религиозные верования и прославления православной цуеркви. В России в 2000 году произошло общецерковное прославление святого Луки, как признание святости Бога, что оказалась в его жсизи. Святой Лука получил почетное место в истории медицины и Восточной Православной Церкви. Это исследование имеет иелью осветить ключевые элементы его жсизи и его научный вклад.

Ключевые слова: Святой Лука; Войно-Ясенецкий; лекарства; наука Симферополь

Received 07.03.2021

Received in revised form 03.05.2021

Accepted 17.05.2021. 